\title{
FUNGSI NGAROT UNTUK MASYARAKAT LELEA
}

\section{THE FUNCTION OF NGAROTS FOR LELEA SOCIETY}

\author{
Ria Intani Tresnasih \\ Lasmiyati \\ Balai Pelestarian Nilai Budaya Jawa Barat \\ Jln. Cinambo 136 Ujungberung-Bandung \\ e-mail: kemuning13@gmail.com \\ e-mail: lasmiyatinizam@gmail.com
}

\begin{abstract}
Abstrak
Ngarot merupakan upacara yang memiliki keterkaitan dengan masalah pertanian.Upacara ini terdapat di Desa Lelea, Kecamatan Lelea, Kabupaten Indramayu.Upacara ngarot diikuti oleh generasi muda dan berlangsung dari tahun ke tahun tanpa putus. Keikutsertaan generasi muda serta keberlangsungan upacara ini memunculkan pertanyaan apa yang menjadi tujuan upacara, seperti apa bentuk dari upacara ngarot, dan apa sesungguhnya fungsi dari upacara ngarot itu untuk generasi muda khususnya dan masyarakat Lelea pada umumnya. Sehubungan dengan pertanyaan tersebut, penelitian ini bertujuan untuk mengetahui tujuan upacara, bentuk dari upacara ngarot, dan fungsi upacara itu bagi generasi muda khususnya dan masyarakat Lelea pada umumnya. Jenis penelitian ini deskriptif dengan pendekatan yang digunakan adalah kualitatif. Hasil penelitian menunjukkan bahwa upacara ngarot menjadi wadah untuk mempersatukan pemuda Lelea, menjadi wadah untuk melekatkan rasa gotong royong antarpemuda Lelea, dan mengajarkan pemuda untuk hidup mandiri dengan mendayagunakan potensi desanya. Simpulan yang dapat ditarik dari penelitian adalah bahwa upacara ini tidak lain sebagai sarana sosialisasi kepada generasi muda Lelea, agar mereka senantiasa dapat mencintai desanya.
\end{abstract}

Kata kunci: fungsi, upacara Ngarot, masyarakat Lelea.

\section{Abstract}

Ngarot is a ritual that has been linked to farming problems. This ritual occurs in Lelea village, District of Lelea, Indramayu. Ngarot ceremony followed by the younger generation and continuosly lasts from a year to a year. The participation of the younger generation as well as the sustainability of this ceremony raises the question on what the purpose of the ceremony is, what Ngarot is, and what the real function of the Ngarot ceremony is for the younger generation in particular and Lelea society in general. In connection with these questions, this study aims to determine the purpose of the ceremony, the form and ritual of ngarot ceremony is for the younger generation, in particular and Lelea society, in general. It is descriptive study with the qualitative approach. The results showed that Ngarot ceremony of Lelea is a means to unite the Lelea youth, become a means to attach a sense of mutual cooperation among the Lelea youth, and teaches youth to be independent by empowering the potential of the village. The conclusion that can be drawn from the research is this ceremony was seen as a means of socialization to the younger generation of Lelea, so they can always love the village.

Keywords: Function, Ngarot, Lelea Society 


\section{A. PENDAHULUAN}

Terdapat beberapa pengertian terkait dengan istilah upacara tradisional. Rahmat Subagio mengartikan upacara tradisional sebagai kelakuan simbolis manusia yang mengharapkan keselamatan, yang merupakan rangkaian tindakan yang diatur oleh adat yang berlaku, serta berhubungan dengan berbagai macam peristiwa tetap yang biasa terjadi dalam masyarakat yang bersangkutan (Herlinawati, 2011: 298).

Menurut Suyono (Merlina, 2015: 250), upacara mengandung arti berdasarkan upacara itu sendiri, namun pada dasarnya upacara merupakan suatu pesta tradisional yang telah diatur menurut tata adat atau hukum yang berlaku dalam masyarakat. Adapun menurut Budhisantoso bahwa berbagai upacara dikembangkan dengan maksud untuk menyampaikan gagasan dan pengalaman pendahulunya, untuk mengukuhkan pendapat, norma-norma, dan agama dengan lambang-lambang (Intani T., 2009: 85). Hal senada disampaikan oleh Nina Merlina (2015: 251), upacara merupakan salah satu cara untuk mengenal sejarah, selain mengenal mitologi dan legenda pada suatu masyarakat tertentu yang belum mengenal tulisan (baca: pada zamannya).

Pengertian lain dari upacara tradisional diberikan oleh Al-Hasani (2014: 1220), yakni sebagai salah satu pranata sosial religius yang diperlukan masyarakat sebagai usaha untuk memenuhi komunikasi dengan kekuatan magis atau roh leluhur.

Dari berbagai pendapat di atas menunjukkan bahwa upacara tradisional bukan merupakan suatu aktivitas seharihari. Sifatnya sakral oleh karena selalu berhubungan dengan Sang Pencipta dan para leluhur dari pendukung upacara. Selanjutnya, bagaimanapun bentuk dari upacara tradisional yang dilaksanakan selalu bermuara untuk keselamatan dan kesejahteraan. Sifat upacara tradisional tidak transparan, melainkan berbalut simbol yang menyimpan sejuta pesan dari leluhur untuk dilaksanakan oleh generasi penerusnya. Simbol upacara dapat dilambangkan melalui gerakan, perlengkapan upacara, ataupun melalui warna-warni benda yang digunakan dalam upacara. Olehkarenanya, upacara tidak serta merta dapat dilakukan begitu saja, melainkan terikat oleh tata cara yang berlaku dari awal adanya hingga menurun dari generasi ke generasi berikutnya.

Upacara tradisional jenisnya bermacam, namun secara garis besar terbagi atas upacara daur hidup yaitu upacara yang menandai terjadinya peralihan dari satu fase ke fase kehidupan berikutnya. Dimulai dari fase kehamilan kelahiran - fase anak - fase remaja - fase dewasa - fase tua - kematian; dan upacara ruwatan (meruwat). Upacara ini dilaksanakan sebagai upaya untuk menolak bala dan untuk mendapatkan kesejahteraan. Termasuk di dalam upacara ini adalah upacara yang ada hubungannya dengan pertanian. Indonesia yang dikenal sebagai negara agraris, wajar apabila sebagian besar masyarakatnya bergelut dalam bidang pertanian. Dengan kata lain, sawah masih menjadi lahan garapan yang dominan. Tidak heran, hingga saat ini, beras masih menjadi makanan pokok atau makanan unggulan untuk sebagian besar masyarakat Indonesia. Beberapa daerah di Jawa Barat, menjadi penopang untuk memenuhi kebutuhan makanan pokok tersebut. Salah satunya adalah Kabupaten Indramayu.

Kabupaten Indramayu memiliki luas wilayah 118.011 hektar. Dari luas wilayah tersebut,57.94\%-nya merupakan lahan pesawahan ${ }^{1}$. Itu artinya bahwa separuh lebih dari luas wilayah di Kabupaten Indramayu merupakan daerah pesawahan. Meskipun zaman sudah serba teknologi, namun sebuah wilayah yang masih memiliki sawah yang cukup luas, terkadang masih melaksanakan upacara

\footnotetext{
${ }^{1}$ http://www.bappedaindramayukab.go.id
} 
tradisional yang berkaitan dengan pertanian. Entah itu upacara sebelum mengerjakan sawah atau memulai menanam padi, merawat padi, hingga upacara panen. Begitu pula dengan Kabupaten Indramayu.

Terkait dengan upacara pertanian yang berlangsung di Indramayu, terdapat di antaranya ada upacara sedekah bumi, mapag tamba, mapag sri, dan ngarot. Upacara pertanian seperti sedekah bumi, mapag tamba, dan mapag sri, banyak pula terdapat di sebagian wilayah di Jawa Barat dengan istilah yang sama atau berbeda.

Adapun upacara ngarot, berbeda dibandingkan dengan upacara tradisional pertanian pada umumnya. Perbedaan yang sangat mencolok adalah pada peserta upacaranya yang tidak lain adalah generasi muda. Dari mulai anak-anak hingga remaja. Padahal, pada upacara pertanian lainnya, umumnya diikuti oleh orang tuatua.

Adanya fenomena yang tidak umum pada peserta/pelaku upacara itu, memunculkan beberapa pertanyaan. Apa sesungguhnya tujuan dari penyelenggaraan upacara ngarot, seperti apa bentuk upacaranya, dan apa fungsinya bagi generasi muda khususnya dan masyarakat Lelea pada umumnya.

Sehubungan dengan beberapa pertanyaan tersebut, dilakukanlah penelitian pada upacara ngarot. Penelitian ini dilakukan dengan tujuan untuk mengetahui tujuan dari upacara ngarot, gambaran secara menyeluruh dari upacara ngarot tersebut, dan fungsinya bagi masyarakat pendukungnya, khususnya generasi muda.

Agar penelitian ini tetap konsisten pada tujuannya maka materi yang akan diteliti dibatasi ruang lingkupnya. Materi yang diteliti meliputi: nama dan sejarah lahirnya upacara ngarot, tujuan penyelenggaraan upacara, waktu dan tempat penyelenggaraan upacara, persiapan dan perlengkapan upacara, teknis penyelenggaraan upacara, pihakpihak yang terlibat dalam upacara, jalannya upacara, makna yang terkandung dalam upacara, dan pantangan yang berlaku. Selain itu diteliti pula fungsi dari upacara sehingga akan dipahami oleh masyarakat di luar Lelea mengapa upacara ngarot tersebut diikuti oleh generasi muda dan mengapa upacara itu hingga kini masih terus diselenggarakan.

Adapun ruang lingkup wilayahnya dibatasi di Desa Lelea, tempat awal upacara ini ada.

\section{B. METODE PENELITIAN}

Penelitian upacara ngarot ini bersifat deskriptif dengan pendekatan kualitatif. Penelitian deskriptif bertujuan untuk menggambarkan, meringkaskan berbagai kondisi, berbagai situasi, atau berbagai fenomena realitas sosial yang ada di masyarakat yang menjadi objek penelitian, dan berupaya menarik realitas itu ke permukaan sebagai suatu ciri, karakter, sifat, model, tanda, atau gambaran tentang kondisi, situasi, ataupun fenomena tertentu (Bungin, 2009: 68).

Adapun pendekatan kualitatif, menurut Zulyani Hidayah digunakan untuk memahami persoalan sosial atau budaya manusia berdasarkan pada suatu pengembangan gambaran yang kompleks dan holistis, dibangun dengan susunan kata-kata, menyajikan pandangan detail dari informan dan dilaksanakan di lingkungan alamiahnya. Studi kualitatif juga dilaksanakan dalam situasi peneliti berinteraksi secara langsung dengan orangorang yang diteliti, dalam upaya memeroleh data dari sumber pertama (Somantri, 2012: 139).

Teknik analisis data yang dilakukan adalah analisis kualitatif yang bersifat deskriptif interpretatif. Prosedur yang digunakan dalam analisis tersebut mencakup tahapan klasifikasi, interpretasi, dan penarikan kesimpulan.Wirata mengatakan bahwa alur dalam menganalisis adalah melakukan seleksi data terlebih dahulu berdasarkan realibilitasnya. Selanjutnya, data yang lolos seleksi diinterpretasikan untuk 
dilakukan penarikan kesimpulan sebagai jawaban atas permasalahan yang diajukan dalam penelitian (Intani T., 2015: 512513).

Terkait dengan sifat dan pendekatan yang digunakan dalam penelitian ini maka pemaparan upacara ngarot diupayakan menyeluruh dari "A hingga Z", sebagaimana dijabarkan di dalam ruang lingkup materi penelitian. Selanjutnya oleh karena pendekatan kualitatif bermuara pada hasil nonangka, alias "pendapat" dari informan maka teknik perolehan data dalam penelitian ini dilakukan dengan wawancara. Wawancara dilakukan terhadap beberapa informan seperti pemangku adat, tokoh masyarakat, dan pemangku budaya dari instansi terkait. Pelaksanaan wawancara dilakukan dengan menggunakan pedoman wawancara agar penelitian tetap terarah. Wawancara sifatnya terbuka dalam arti informan tidak diberikan pilihan jawaban dari setiap pertanyaan yang diajukan, melainkan informan diberikan kebebasan untuk memberikan jawabannya.

Demi melengkapi data dari wawancara maka dilakukan pula pengambilan data dengan pengamatan. Namun demikian oleh karena penelitian ini tidak dilakukan pada saat berlangsungnya upacara maka pengamatan dilakukan pada hasil-hasil rekaman video baik dari DVD maupun media internet. Metode pengamatan menurut Kasnodihardjo tepat digunakan untuk sasaran penelitian mengenai perilaku/tindakan dan benda (1992: 18). Mata rantai dari obyek pengamatan tadi adalah bermuara pada penggunaan gambar/foto yang diambil dari media internet.

Kerangka berpikir dalam penelitian ini bertitik tolak dari konsep yang dikemukakan oleh Bronislaw Malinowski yang mengatakan bahwa ada empat unsur pokok kebudayaan, yakni:

- sistem norma sosial yang memungkinkan kerja sama antara para anggota masyarakat untuk menyesuaikan diri dengan alam sekelilingnya;
- organisasi ekonomi;

- alat-alat dan lembaga atau petugas untuk pendidikan (keluarga adalah lembaga pendidikan utama);

- organisasi kekuatan (politik) (Saebani, 2012: 163).

Selain itu, kebudayaan juga diartikan secara luas seperti yang dikemukakan oleh Edward Burnett Tylor (Saebani, 2012: 162). Kebudayaan diartikan sebagai keseluruhan yang kompleks, yang di dalamnya terkandung pengetahuan, kepercayaan, kesenian, moral, hukum, adat istiadat, dan kemampuan lain yang didapat seseorang sebagai anggota masyarakat.

Selanjutnya sebagai pisau analisis untuk penelitian ini digunakan teori struktur fungsionalisme dari Malinowski. Teori ini mengemukakan bahwa fungsi diwajibkan untuk memenuhi kebutuhan (needs), karena fungsi menjadi sesuatu yang melayani kehidupan dan kelanjutan hidup (Rusnandar, 2013: 85). Dengan kata lain, segala sesuatu masih akan diperlukan selama masih berfungsi bagi masyarakatnya.

Menurut Budhi Santoso, fungsi upacara dapat dikaji dengan melihat fungsinya sebagai: norma sosial, pengendali sosial, media sosial, dan pengelompokan sosial (Intani T., 2009: $85)$.

Norma, menurut Koentjaraningrat (1990: 5) merupakan wujud ideel dari kebudayaan sehingga sifatnya abstrak, tak dapat diraba. Lokasinya ada di dalam alam pikiran dari warga masyarakat di mana kebudayaan yang bersangkutan hidup.

Selanjutnya juga dikatakan oleh Koentjaraningrat (1990: 5-6) bahwa kebudayaan ideel itu juga dapat disebut sebagai adat tata kelakuan. Sebabnya, kebudayaan ideel itu biasanya juga berfungsi sebagai tata kelakuan yang mengatur, mengendali, dan memberi arah kepada kelakuan dan perbuatan manusia dalam masyarakat. 


\section{Tinjauan Pustaka}

Penelitian mengenai upacara yang berkaitan dengan pertanian bukanlah merupakan penelitian yang pertama. Dalam hal kaitannya dengan upacara ngarot, terdapat beberapa informasi di media maya. Namun informasi tersebut sifatnya sekilas, tidak detail. Informasi yang agak lengkap terdapat dalam hasil perekaman yang dilakukan oleh penulis sendiri bersama dengan beberapa rekan di tahun 1992. Namun demikian, hasil perekaman tersebut sifatnya deskriptif karena bukan merupakan hasil penelitian, sehingga tidak menyinggung pada fungsi upacaranya.

Sehubungan dengan itu, untuk dapat memahami lebih jauh perbedaan penelitian ini dengan penelitian lainnya maka perlu kiranya diuraikan beberapa hasil penelitian terdahulu yang mengangkat topik seputar bidang pertanian. Dengan demikian akan lebih memperjelas alasan kelayakan untuk melakukan penelitian ini.

Berikut adalah beberapa literatur yang direview dari hasil penelitian:

- Judul:

Makna Simbolik dalam Ritual Kawit dan Wiwit pada Masyarakat Pertanian di Desa Ngasemlemahbang Kec. Ngimbang Kab. Lamongan, tahun 2014.

- Penulis:

Mohammad Muwatiqilah Al Haseni dan Oksiana Jatiningsih

- Hasil Penelitian:

Hasil penelitian menunjukkan bahwa kawit adalah sebuah ritual yang dilakukan masyarakat pertanian sebelum dan sesudah bercocok tanam padi. Kawit dilakukan sebagai harapan agar masyarakat mendapat hasil panen yang melimpah. Adapun wiwit diartikan sebagai sesuatu yang paling dahulu atau yang pertama kali, dalam hal ini adalah padi yang paling dahulu berbuah atau berisi sebelum dipanen. Wiwit yaitu sebuah ritual yang dilakukan menjelang masa panen sebagai ungkapan rasa syukur petani atas hasil panen padi. Di dalam upacara baik kawit maupun wiwit terdapat beberapa kelengkapan yang mengandung simbol, yang memiliki makna tertentu.

\section{- Perbandingan:}

Kesamaan antara ritual kawit dan wiwit dengan upacara ngarot, sama-sama berkaitan dengan bidang pertanian. Upacaranyapun sama-sama bersifat kolektif dan menggunakan simbol-simbol yang dilekatkan dalam kelengkapan upacara. Namun demikian antara ritual wiwit dan apalagi kawit terdapat perbedaan dengan ngarot. Perbedaan terletak pada waktu dan tempat pelaksanaan, pada tujuan upacara, dan pada peserta upacaranya. Selain itu, perbedaan yang lebih mendasar adalah kalau ritual kawit dan wiwit lebih menekankan pada aspek simbolisnya, sedangkan upacara ngarot lebih menekankan pada fungsinya.

\section{-Judul:}

\section{Peranan Dewi Sri dalam Tradisi} Pertanian di Indonesia, tahun 2014.

\section{- Penulis:}

Sri Trisna Dewi Hartati

\section{- Hasil Penelitian:}

Hasil penelitian menunjukkan bahwa Dewi Sri dianggap sebagai ruh yang menghadirkan kesukacitaan dan kebahagiaan. Dewi Sri digambarkan sebagai seseorang yang cantik jelita, bisa terbang dan senantiasa menyunggingkan senyum yang anggun. Dewi Sri diletakkan pada tempat yang tertinggi. Pada saat panen, petani akan mengambil satu tangkai yang dipersembahkan kepada Dewi Sri agar hasil panen mendatang jauh lebih baik. Dengan demikian subjek dalam upacara ini adalah Dewi Sri. 
- Perbandingan:

Upacara ini memiliki keserupaan dengan upacara ngarot. Keserupaan terletak pada adanya subjek yang dianggap berkontribusi dalam keberhasilan panen. Meskipun demikian, kedua penelitian ini memiliki perbedaan yang mendasar. Di dalam upacara terdahulu subjeknya adalah Dewi Sri, sedangkan dalam upacara ngarot yang menjadi subjeknya adalah generasi muda.

\section{- Judul:}

Nilai Pendidikan dalam Budaya Menanam Padi Suku Dayak Kanayatn di Kalimantan Barat, tahun 2012.

- Penulis:

Neni Puji Nur Rahmawati

- Hasil Penelitian:

Hasil penelitian menunjukkan bahwa masyarakat Dayak Kanayatn memiliki kearifan lokal dalam bidang pertanian. Kearifan lokal tersebut berkontribusi pada penanaman nilai-nilai luhur kepada masyarakatnya.

- Perbandingan:|

Upacara ini memiliki keserupaan dengan upacara ngarot. Keserupaan terletak pada adanya kearifan lokal di dalam upacara. Namun demikian, perbedaan yang mendasar terdapat antarkeduanya. Penelitian terdahulu lebih menekankan pada tata cara menanam padi sebagai kearifan lokalnya, sedangkan pada upacara ngarot lebih menekankan pada orang yang menanam.

\section{- Judul:}

Fungsi Upacara Pertanian pada Masyarakat Guradog Kabupaten Lebak, tahun 2009.

- Penulis:

Ria Intani T.

-Hasil Penelitian:
Hasil penelitian menunjukkan bahwa terdapat banyak upacara pertanian pada masyarakat Guradog. Kesemua upacara tersebut pada umumnya memiliki tujuan yang sama, yakni untuk mendapatkan keselamatan dan keberhasilan dalam panen.

- Perbandingan:

Baik upacara-upacara pertanian di Guradog maupun upacara ngarot, samasama bermuara untuk kesejahteraan masyarakatnya. Namun demikian terdapat perbedaan antar- keduanya. Perbedaannya, penelitian terdahulu tidak membatasi pada satu materi upacara, melainkan pada semua upacara pertanian yang ada. Selain itu, kalau di dalam upacara-upacara pertanian di Guradog, kesejahteraan "ditumpukan" pada generasi tua pada umumnya, sedangkan dalam upacara ngarot, lebih ditekankan kepada generasi muda. Dengan demikian, dengan adanya perbedaan tersebut, secara langsung menjadi pembeda pada tujuan upacaranya.

\section{HASIL DAN BAHASAN \\ 1. Gambaran U mum Desa Lelea}

Desa Lelea secara administratif berada di Kecamatan Lelea, Kabupaten Indramayu. Desa ini berluas 422 hektar, sekitar 380 hektar di antaranya merupakan pesawahan. Dengan demikian bercocok tanam padi di sawah merupakan mata pencaharian pokok bagi mayoritas warganya. Menurut Yanti Nisfiyanti (2011: 444), mereka yang menggeluti bidang pertanian terdiri atas petani pemilik, penggarap, dan buruh tani. Saat ini, petani pemilik merupakan jumlah terbesar.

Desa Lelea berjarak 15,5 kilometer persegi dari ibu kota Kabupaten Indramayu. Desa ini memiliki batas-batas wilayah sebagai berikut:

- sebelah selatan berbatasan dengan Desa Pangauban Kecamatan Lelea;

- sebelah barat berbatasan dengan Desa Cempeh Kecamatan Lelea; 
- sebelah timur berbatasan dengan Desa Tamansari Kecamatan Lelea; dan

- sebelah utara berbatasan dengan Desa Larangan Kecamatan Lohbener.

\section{Sejarah Indramayu.}

Dalam cerita rakyat yang berkembang di Indramayu, Wiralodra dan Ki Tinggil merupakan orang yang pertama kali tinggal di hutan Cimanuk. Kegiatan sehari-hari mereka diisi dengan membuka tanah dan berladang.

Ketika Wirolodra pergi ke daerah asalnya, ia mempercayakan hutan Cimanuk kepada Ki Tinggil. Ki Tinggil yang dipercaya sebagai lurah di hutan tersebut melanjutkan membuka hutan dan berladang. Lambat laun mulai banyak pendatang yang bertamu dan bertempat tinggal. Selanjutnya mereka bergotongroyong membangun jalan, saluran air, dan rumah.

Di antara tamu yang datang, terdapat tamu perempuan bernama Nyi Endang Darma disertai pengikutnya. Mereka datang dengan membawa bibit yang sangat dibutuhkan masyarakat di hutan Cimanuk yaitu jagung, padi, dan palawija. Kedatangan Nyi Endang Darma disambut baik oleh Ki Tinggil. Selanjutnya mereka mencari tempat untuk tinggal dan bercocok tanam. Nyi Endang Darma pun tidak segan-segan untuk memberikan ilmunya kepada yang lain bagaimama cara bercocok tanam.

Di wilayah Jawa Barat, kegiatan pertanian dengan sistem sawah dimulai setelah adanya kerajaan Islam di Jawa Barat yang pusat penyebarannya di Cirebon dan Banten. Pembukaan sawah terus dilakukan di daerah Karawang sampai daerah sebelah barat Sungai Cimanuk (Ekadjati dalam Chijs, 1995: 103). Pembukaan daerah pesawahan di daerah Indramayu diperkirakan terjadi pada abad ke-7.

\section{Sejarah Tari Topeng}

Sunan Gunung Jati adalah salah satu dari Walisanga yang menyebarkan agama Islam di Cirebon dan sekitarnya. Para wali melakukan siar Islam dengan beberapa pendekatan seperti melalui bercocok tanam, kesenian, pengobatan, tata niaga, dan struktur pemerintahan. Melalui pendekatan kesenian, Ia menjadikan tari topeng dan wayang kulit sebagai media untuk menyebarkan agama Islam.

Tari topeng yang awalnya berasal dari lingkungan istana Cirebon menyebar ke arah Indramayu. Di Indramayu tari topeng yang semula sebagai tarian keraton tersebut berubah menjadi tarian rakyat. Tari topeng yang menyebar ke arah Indramayu, bentuk topeng dan tokohnya sama dengan di Cirebon, yang berbeda adalah gerak tariannya ${ }^{2}$.

Sejak keberadaannya di Indramayu dan dengan melihat dari faktor sejarahnya maka tari topeng menjadi jenis kesenian yang wajib ada dalam upacara ngarot. Selain tari topeng menjadi unsur hiburan di dalam pelaksanaan upacara ngarot, juga menjadi media tuntunan oleh karena ada simbol-simbol yang dilambangkan dengan penggunaan beberapa jenis topeng dan gerakan penari, yang masing-masing menggambarkan dari mulai fase bayi, anak-anak, remaja, dewasa, hingga tua. Keseluruhan simbol tersebut bermakna bahwa semua yang hidup akan berakhir dengan kematian. Oleh karenanya, semasa hidup hendaknya diisi dengan berkarya dan beramal sesuai dengan tingkatan umur dan kemampuannya.

\section{Sejarah Ronggeng Ketuk}

Ronggeng ketuk merupakan salah satu seni tari tradisional yang terdapat di Kabupaten Indramayu. Ronggeng ketuk termasuk ke dalam jenis tari pergaulan. Tidak diketahui secara pasti sejak kapan kesenian ini ada pada awalnya.

Selain berfungsi sebagai media hiburan, pada zamannya, ronggeng ketuk juga sering dipanggil untuk acara khaul. Ronggeng seringkali tampil untuk

\footnotetext{
${ }^{2}$ (http://sanggarcendrawasih.wordpress.com)
} 
melayani penonton yang berminat menari bersamanya. Ronggeng ketuk sebagaimana namanya, diiringi nayaga dengan waditranya berupa ketuk, rebab, gendang dengan kulanter-nya, gong, dan kecrek.

Pada zamannya, ronggeng ketuk tampil semalam suntuk, dari usai isya hingga menjelang subuh. Namun demikian seiring berjalannya waktu, ronggeng ketuk hanya diperbolehkan tampil di malam hari saja.

Demi menjaga kelestarian kesenian Indramayu maka kesenian ronggeng ketuk diharuskan ditampilkan dalam setiap pelaksanaan upacara ngarot. Apalagi, beberapa penari ronggeng ketuk, termasuk salah satu primadonanya saat itu, Mimi Tiweng, berasal dan tinggal di Kecamatan Lelea ${ }^{3}$.

\section{U pacara $\mathrm{N}$ garot}

\section{a. Sejarah U pacara}

Upacara ngarot dilatari oleh peristiwa adanya seorang tokoh masyarakat bernama Ki Kapol. Semasa hidupnya, ia senang mengumpulkan bujang-cuene (muda-mudi) sambil mengadakan makan-makan dan minum di tempat tinggalnya. Oleh karena rasa sayang bujang-cuene kepada Ki Kapol, sebagai balas jasa, mereka secara gotong royong membantu menggarap sawah milik Ki Kapol yang berluas 2, 610 hektar pada waktu itu. Kesempatan itu sekaligus digunakan untuk memberikan pembelajaran cara bertani yang benar.

Kegiatan tersebut berjalan terus setiap tahun dan dalam perkembangannya disertai hiburan berupa kesenian topeng dan ronggeng ketuk. Setelah masa penjajahan Belanda ditambah dengan kesenian jidur (tanjidor).

Manakala Ki Kapol menduduki jabatan kuwu (kepala desa) Desa Lelea, kegiatan bujang-cuene dipindahkan dari balai adat (rumah Ki Kapol) ke balai desa. Ketika Ki Kapol habis masa jabatannya sebagai kuwu, karena Ki Kapol tidak

${ }^{3}$ (http:/pensilwarnadesign.wordpress.com). mempunyai keturunan, sawah miliknya yang biasa digarap bujang-cuene diserahkan ke pemerintah desa dengan syarat pesta bujang-cuene tersebut harus tetap berjalan. Selanjutnya, pesta bujangcuene tersebut dinamai upacara ngarot. Kata ngarot berasal dari bahasa Sunda Lelea yang artinya makan-minum (Samian, 1992: 1).

Demikian kegiatan terus berlangsung pada setiap tahunnya.Setiap dua minggu usai acara pesta (upacara ngarot), bujang-cuene kemudian ditugasi untuk durugan (menggarap sawah). Ada kepercayaan apabila sawah warisan tersebut digarap oleh bujang-cuene, hasilnya akan baik.

Kepercayaan ini menguat oleh karena dilatari adanya suatu peristiwa. Saat itu, seorang kuwu tidak menyetujui sawah kasinoman digarap oleh bujang-cuene. Ketidakpercayaan tersebut karena melihat hasil kerja bujang-cuene yang dianggap kurang baik. Yakni, jarak penanamannya kurang beraturan.

Adanya anggapan seperti itu, pengolahan sawah lalu diserahkan kepada kuli. Namun demikian ternyata hasilnya bukan menjadi lebih baik, melainkan padi banyak terserang hama. Sejak itu, tradisi yang sudah dirintis oleh $\mathrm{Ki}$ Kapol dikembalikan seperti pada awalnya.Yakni, sudah menjadi keharusan sawah warisan Ki Kapol digarap oleh bujang-cuene.

Berikutnya, oleh karena sawah milik Ki Kapol tersebut digarap oleh bujang-cuene maka sawah tersebut disebut sebagai sawah kasinoman. Istilah kasinoman berasal dari kata enom yang artinya muda.

Upacara ngarot telah berlangsung sejak abad ke-16. Sebutan ngarot diucapkan oleh masyarakat Lelea maupun luar Lelea. Sedangkan istilah kasinoman, hanya merupakan istilah intern atau dengan kata lain hanya digunakan oleh masyarakat Lelea. Kasinoman berasal dari kata enom (orang muda) atau sinom (daun asam yg muda). Daun asam yang muda terlihat bercahaya dan indah, sehingga 
banyak disukai orang. Demikian halnya harapan dari para peserta upacara.

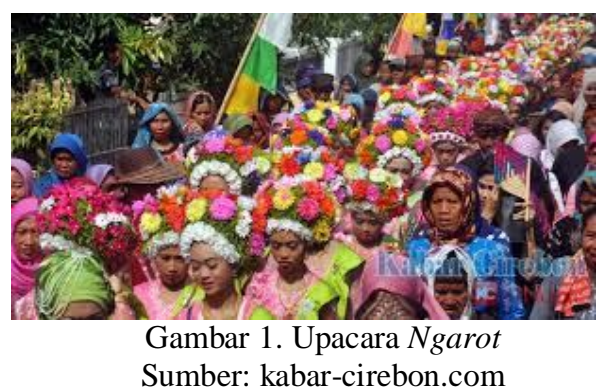

\section{b. Tujuan U pacara}

Sebagaimana yang disampaikan oleh kuwu Desa Lelea, Samian (1992: 2) dan kuwu-kuwu penerusnya, upacara ngarot diselenggarakan untuk beberapa tujuan:

Pertama, bertujuan sebagai wadah untuk mempersatukan pemuda Desa Lelea. Kedua, bertujuan untuk melekatkan rasa gotong-royong antarpemuda di Desa Lelea. Ketiga, bertujuan mendewasakan pemuda dengan dituntut kemandiriannya.

Tujuan yang ketiga tersebut sesuai dengan pituah kokolot Lelea (petuah sesepuh Lelea) yang disampaikan dalam bahasa Sunda Lelea sebagai berikut:

"mikirun budak engkena kuma'a, senajan boga arta kudu tetep usa'a. Kur ngora ula poya - paya, kamberan kolota ula sengsara. Dlema laki kerja, ewena usa'a. Neangan pekaya rukun runtut, aturan agama kudu diturut slamet dunya akherat" (Samian, 1992: 2).

Pada intinya petuah tersebut mengandung nasihat yang ditujukan untuk anak-anak muda di Lelea, agar mereka mengisi masa mudanya dengan bekerja keras, serta selalu berpedoman pada ajaran agama agar kehidupan mereka selamat dunia dan akhirat.

Selanjutnya, tujuan-tujuan tersebut di atas dijabarkan lebih jauh dengan menanamkan rasa cinta bertani kepada generasi muda yang ada di Lelea.
Tujuan ini memiliki benang merah dengan potensi Desa Lelea sebagai daerah pesawahan. Dengan adanya rasa cinta untuk menekuni bidang pertanian, diharapkan mampu mencegah anak-anak muda Lelea untuk merantau.

Selain tujuan-tujuan di atas, tujuan diselenggarakannya upacara juga untuk menyeragamkan dimulainya musim tanam, sekaligus memberi komando bahwa tanam padi sudah dapat dimulai.

\section{c. Waktu dan Tempat Penyelenggaraan Upacara}

Upacara ngarot diselenggarakan pada bulan-bulan musim penghujan, antara November-Desember. Harinya, hari Rabu. Adapun tanggal pelaksanaannya bergantung hasil musyawarah antara pemangku adat dan para tokoh masyarakat setempat.

Awalnya, ngarot diselenggarakan di balai adat. Setelah Ki Kapol menjabat sebagai kuwu Desa Lelea, acara dipindahkan ke balai desa. Tempat lain yang terkait dengan penyelenggaraan upacara adalah rumah ketua RT untuk tempat berkumpul peserta upacara, serta rumah kuwu sebagai tempat pemberangkatan awal menuju balai desa.

\section{d. Teknis Penyelenggaraan U pacara}

Teknis penyelenggaraan ngarot dimulai dua bulan sebelum hari pelaksanaan. Tahap awal, dilakukan rembug desa (musyawarah) untuk menentukan waktu penyelenggaraan upacara.Tahap berikutnya dibentuk kepanitiaan yang terdiri atas: kuwu bapa kuwu biang (kepala desa beserta istri), pamong desa bersama istri, polisi desa, serta instansi terkait.

Penyelenggaraan upacara ngarot dibiayai dari hasil panen sawah kasinoman pada musim tanam sebelumnya, dan untuk penyelenggaraan berikutnya dibiayai dari hasil panen sawah kasinoman tahun berikutnya, demikian seterusnya.

Informasi tentang penyelenggaraan upacara ngarot diumumkan sebulan 
sebelum penyelenggaraan upacara, yakni pada saat upacara sedekah bumi. Sebagaimana tradisi yang sudah berlangsung, teknik pengumuman selain menggunakan pengeras suara, juga dengan memukul bende keliling desa.

Dua minggu dari waktu pengumuman, bujang-cuene yang akan menjadi peserta ngarot berkumpul di balai desa untuk memusyawarahkan warna seragam yang akan dikenakan saat upacara, sekaligus menunjuk beberapa di antaranya sebagai perwakilan dalam acara serah terima perlengkapan tani.

\section{e. Pihak-pihak yang Terlibat dalam U pacara}

Secara garis besar, pihak yang terlibat dalam upacara terbagi atas: pelaku upacara, pelindung/penasihat penyelenggaraan upacara, keamanan, dan partisipan.

Pelaku upacara terdiri atas: bujang-cuene, kuwu bapa kuwu biang dan pamong desa beserta istri, serta penari topeng dan ronggeng ketuk. Pelindung/penasihat adalah pejabat atau pemangku budaya dari instansi terkait. Keamanan dari polisi desa, sedangkan partisipan adalah mereka yang turut meramaikan acara, seperti: peserta karnaval dan peserta pasar malam.

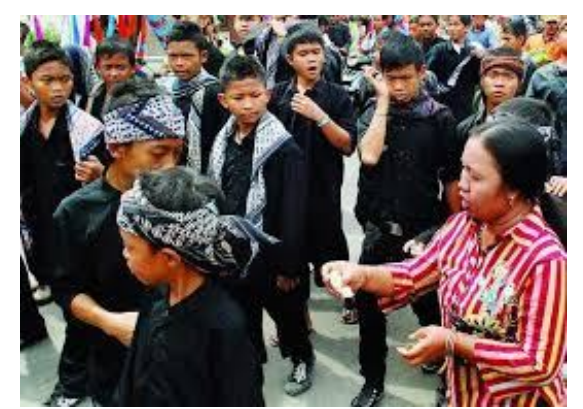

Gambar 2. Para Bujang Sumber: http://www.tosupedia.com,

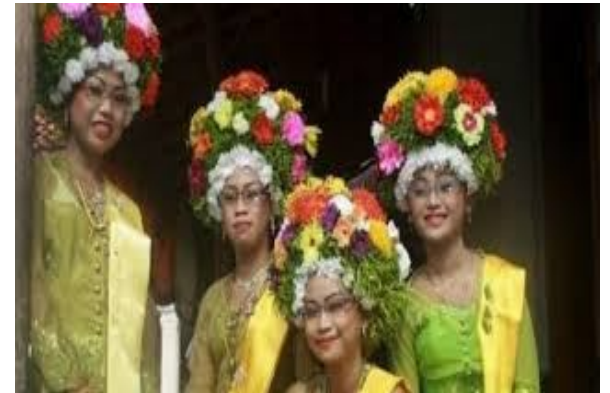

Gambar 3.Para Cuene

Sumber :http://news.fajarnews.com

\section{f. Persiapan dan Perlengkapan U pacara}

Beberapa kegiatan dilakukan sehari menjelang pelaksanaan upacara, seperti: Menata area upacara di balai desa yang dilakukan oleh pamong desa; Menyiapkan bahan-bahan untuk pembuatan nasi kuning dan sesajen yang dilakukan oleh istri pamong desa; Membuat rangkaian bunga kenanga dan melati untuk dikenakan cuene oleh masing-masing orang tua cuene; Orang tua cuene (bagi yang mau), melakukan ziarah ke makam leluhur.

Manakala bahan-bahan untuk memasak nasi kuning telah tersedia, dini hari memasuki hari pelaksanaan upacara, istri pamong desa memasak nasi kuning untuk konsumsi pada saat acara di balai desa. Sementara itu, di masing-masing rumah bujang-cuene, disibukkan oleh kegiatan berdandan.

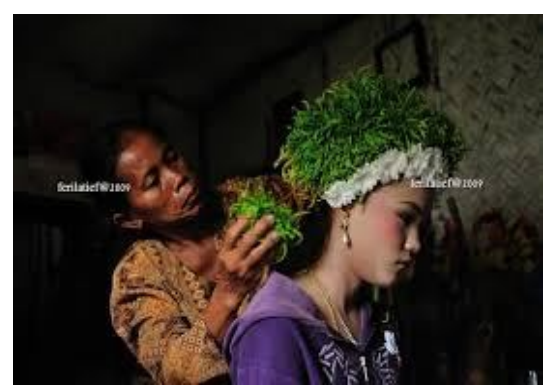

Gambar4. Merias Kepala dengan Rangkaian Kenanga

Sumber: http:// nanakartawi.blogspot.co.id

Secara garis besar, perlengkapan upacara terbagi atas: 
berupa:

Perlengkapan bujang-cuene

- pakaian cuene: kebaya, selendang, sewet (kain panjang), setagen (ikat pinggang), sandal/selop.

- perlengkapan rias wajah;

- perhiasan setenong: bros, jepit kain, untaian peniti, cincin, gelang, kalung, giwang.

- hiasan rambut berupa warna-warni bunga dari kertas jagung yang dibuat oleh pengrajin bunga, rangkaian kenanga, dan melati. Adapun janur yang dibentuk segi tiga, disebut cunduk/pudak, dikenakan cuene yang sudah bertunangan sebagai penanda yang bersangkutan tidak boleh diganggu.

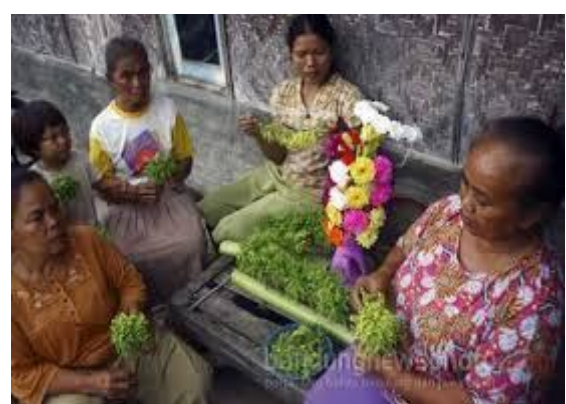

Gambar 5. Pengrajin Bunga Ngarot Sumber:http://www.bandungnewsphoto.com.

- perhiasan dari emas. Banyak sedikitnya perhiasan secara tidak langsung menunjukkan kemampuan ekonomi orang tuanya;

- pakaian bujang berupa komboran (pakaian tani): celana komprang dengan atasan (keduanya serba hitam) dan ikat kepala.

Perlengkapan umum berupa:

- hiasan untuk di balai desa dan tenda;

- peralatan kesenian yang akan tampil;

- bende.

- sesajen

Perlengkapan yang sifatnya sakral:

- perlengkapan tani berupa bibit pare, air, pacul, pedangan, pupuk, dan tanaman penolak bala (kraras, daun cau raja wulung, daun andong, daun beringin, dan bambu kuning).

\section{g. Jalannya U pacara}

Pukul 07.00 WIB, bujang-cuene dari tiap-tiap RT berkumpul di rumah ketua RT masing-masing. Selanjutnya, pada sekitar pukul 08.00, dengan didampingi pamong desa beserta istri, mereka menuju rumah kuwu. Di rumah $k u w u$, peserta upacara disambut kesenian jidur.

Berikutnya, dengan dipimpin kuwu bapa kuwu biang, seluruh peserta upacara melakukan arak-arakan melewati batas desa untuk selanjutnya menuju balai desa. Posisi barisan dalam arak-arakan tidak ada ketentuan pasti, terkecuali untuk kuwu bapa kuwu biang yang selalu ada di depan para cuene atau para bujang.

Barisan arak-arakan terdiri atas: kuwu bapa kuwu biang, para cuene, pamong desa bersama istri, para bujang, grup kesenian jidur, grup kesenian reog dan genjring, nang dan nok Dermayon, dan putra-putri batik.

Sejak tiga tahun terakhir, nang dan nok Dermayon 'putra putri Indramayu terpilih' diikutsertakan dalam penyelenggaraan upacara ngarot. Salah satu tugas mereka adalah untuk mempromosikan pariwisata yang ada di Indramayu, termasuk wisata budayanya. Selain itu, juga diikutsertakan putra putri batik Dermayon yang mengemban tugas untuk mempromosikan batik Dermayon, yang merupakan salah satu ikon Kabupaten Indramayu.

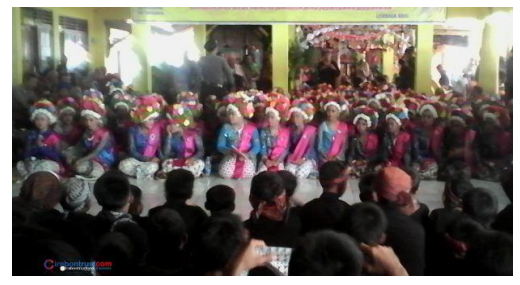

Gambar 6. Acara di bale desa Sumber:http://www.cirebontrust.com 
Acara di balai desa meliputi: Pembukaan; Pituah kokolot Desa Lelea; Mengungkap sejarah ngarot; Amanat kuwu; Penyerahan sarana tani dari kuwu serta pamong desa kepada perwakilan bujang-cuene; Peresmian acara dengan memukul bende. Usai peresmian, ketiga grup kesenian, yakni tari topeng, ronggeng ketuk, dan jidur tampil secara bersamaan di masing-masing tempat yang telah disediakan. Tari topeng menghibur para cuene, sedangkan ronggeng ketuk menghibur para bujang.

\section{h. Pantangan}

Ada beberapa pantangan yang diberlakukan dalam upacara ngarot, yaitu: Pantang menyelenggarakan upacara selain di hari Rabu. Hari Rabu dikisahkan sebagai kedatangan Prabu Lelea ke daerah yang sekarang disebut dengan Lelea. Sebagai penghormatan kepadanya maka upacara dilaksanakan di hari Rabu; Pantang bagi laki-laki dan perempuan yang sudah menikah untuk menjadi peserta upacara. Hal ini terkait pada adanya kepercayaan bahwa sawah kasinoman akan baik hasil padinya apabila penanamannya dikerjakan oleh bujang-cuene; Pantang meniadakan ronggeng ketuk dan topeng dalam upacara $n$ garot.

\section{i. Makna yang Terkandung dalam Upacara}

Ada beberapa makna yang terkandung dalam upacara ngarot, yaitu:

Posisi kuwu bapa kuwu biang di depan bujang-cuene dimaksudkan untuk memberikan tuntunan atau tauladan; Kesegaran bunga dan warna putih pada bunga melati bermakna kesucian; Tari topeng menggambarkan fase kehidupan manusia dari bayi sampai tua, dan akhirnya mati. Hal ini menjadi peringatan agar semasa hidup hendaknya manusia mengisinya dengan hal-hal yang positif; Air, kraras, daun cau raja wulung, daun andong, daun beringin, dan bambu kuning dimaksudkan sebagai penolak bala.

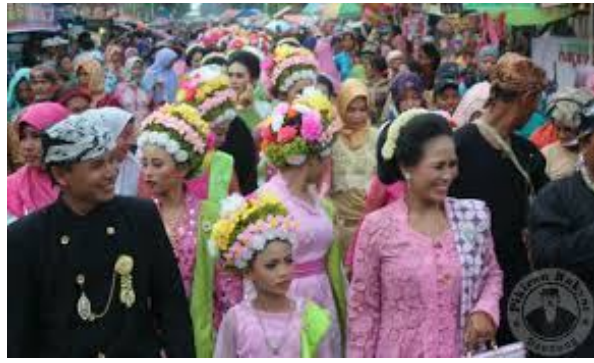

Gambar 7. Kuwu Bapa Kuwu Biang Ada di Barisan Paling Depan

Sumber: Pikiran rakyat.com

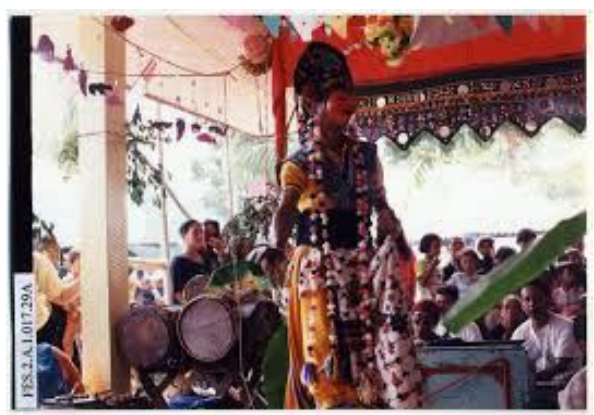

Gambar 8.Tari Topeng

Sumber: Lpsn.infocontencarpa

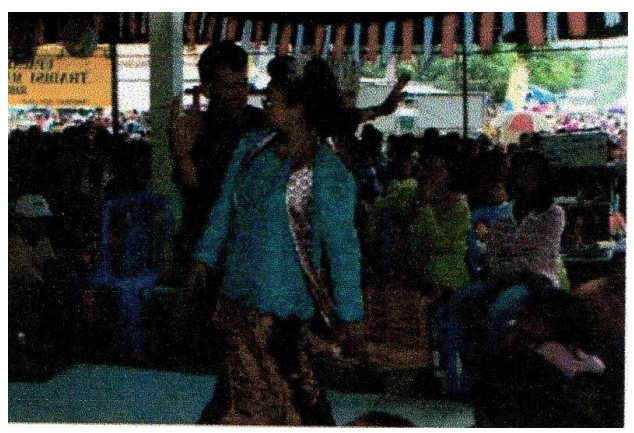

Gambar 9.Ronggeng Ketuk

Sumber: Lina Marliana 2014

\section{j. Fungsi U pacara}

Sebagaimana teori fungsi mengatakan bahwa sesuatu akan dipentingkan apabila masih berfungsi bagi masyarakatnya. Dalam hal kaitannya dengan upacara ngarot, dengan melihat upacara tersebut selalu diselenggarakan tanpa putus dari tahun ke tahun, tentu upacara ini dipandang memiliki fungsi untuk masyarakat Lelea. 
Mengkaji fungsi upacara, dapat dilihat dalam empat hal. Keempat hal tersebut adalah upacara dapat berfungsi sebagai norma sosial, sebagai pengendali sosial, sebagai media sosial, dan sebagai pengelompokan sosial.

Fungsi sebagai norma sosial, pertama, tampak dari tujuan penyelenggaraan upacara yakni: sebagai wadah untuk mempersatukan bujangcuene, melekatkan rasa gotong-royong antara bujang-cuene, melatih bujangcuene untuk lebih mandiri/bekerja keras, tidak meninggalkan ajaran agama, serta menanamkan rasa cinta bertani kepada bujang-cuene. Semua tujuan tersebut sejatinya merupakan norma-norma yang dianut oleh leluhur Lelea untuk diturunkan kepada anak-anak muda Lelea.

Kedua, norma sosial ditunjukkan dengan posisi kuwu bapa kuwu biang yang ada di barisan paling depan pada acara arak-arakan. Ini menyimbolkan bahwa pemimpin harus dapat menjadi suri teladan bagi yang dipimpinnya. Dengan demikian melalui tata cara arak-arakan tersebut dimaksudkan untuk selalu mengingatkan bahwa seorang pemimpin harus dapat menjadi teladan bagi yang dipimpinnya.

Ketiga, norma sosial ditunjukkan pada kesegaran bunga kenanga dan warna putih bunga melati. Ini menyimbolkan bahwa keperawanan/kesucian harus senantiasa dijaga sebagaimana diajarkan dalam agama. Norma sosial juga ditunjukkan pada tampilan tari topeng.

Keempat, penyerahan alat-alat pertanian kepada generasi muda sampai pada penanamannya, mengajarkan kepada bujang-cuene untuk mencintai desanya dengan mendayagunakan potensi yang ada.

Keempat hal di atas dan sebagainya, semuanya menunjukkan norma-norma yang berlaku pada masyarakat Lelea. Dengan demikian, upacara ngarot berfungsi sebagai pengokoh norma social dan ajaran agama oleh karena norma-norma tersebut selalu diulangingatkan setiap tahunnya. Dengan kokohnya norma-norma di masyarakat maka norma-norma tersebut dapat menjadi filter (pengendali) untuk bujangcuene dari hal-hal yang negatif, yang dianggap bertentangan dengan agama dan norma yang berlaku di masyarakatnya.

Dengan terdapatnya beberapa fungsi di atas maka upacara ngarot menjadi media untuk menyampaikan norma-norma dari pendahulunya kepada masyarakatnya, khususnya bujang-cuene. Dan, dengan berkumpulnya/bertemunya bujang-cuene sebagai pelaku upacara, serta masyarakat Lelea secara umum, baik yang masih tinggal di Lelea maupun yang sudah merantau sebagai "penonton" upacara maka upacara ngarot menjadi berfungsi sosial. Melalui upacara ngarot diharapkan dapat menjaga silaturahmi antarwarga. Fungsi sosial juga ditunjukkan dari adanya gotong-royong yang dilakukan oleh para warga, muda maupun tua, dalam mempersiapkan penyelenggaraan upacara. Dengan demikian dengan selalu bersatunya para bujang-cuene, mereka diharapkan mampu mendayagunakan potensi desanya secara bersama-sama. Dengan potensi pesawahan yang dimiliki, diharapkan bujang-cuene tidak harus merantau untuk mencari pekerjaan, namun mau menekuni dunia tani untuk meningkatkan kesejahteraan desanya.

\section{PEN UTU P}

Upacara ngarot merupakan upacara yang memiliki keterkaitan dengan bidang pertanian.Upacara ngarot, seperti upacara pertanian lainnya, tidak dapat dinafikan bermuara pada keselamatan dan kesejahteraan hidup. Namun demikian upacara ngarot berbeda dengan upacaraupacara pertanian pada umumnya. Upacara ini sangat khas dan unik. Upacara ini memiliki tujuan yang kemudian menjadi pembeda dengan upacara pertanian lainnya.

Tujuan pada upacara ngarot identik dengan subjek/peserta/pelaku pada upacara. Subjek/peserta/pelaku dalam 
upacara ngarot adalah bujang-cuene. Oleh karena sebagaimana tujuannya, upacara ini bermaksud menanamkan norma-norma yang berlaku pada masyarakat Lelea kepada bujang-cuene.

Upacara ngarot diselenggarakan dari tahun ke tahun pada hari, bulan, dan tempat yang sama sebagaimana para pendahulunya menyelenggarakan upacara ini. Penyelenggaraan yang tetap ini sifatnya tidak serta merta, melainkan semuanya berasaskan tradisi dan dilatari sejarah.

Secara kasat mata, upacara ngarot tampak sebagai sebuah pesta tradisional semata. Selain ada kemeriahan dari warnawarni bunga yang menghiasi arak-arakan, juga ada kemeriahan dari tampilan beberapa kesenian.

Pesta memang tak dapat dinafikan, hanya saja dibalik yang tersurat tersebut tersirat banyak makna yang disampaikan dalam bentuk simbol-simbol. Simbolsilmbol tersebut apabila dibedah satu-demi satu sejatinya adalah norma-norma masyarakat Lelea.

Zaman memang terus berkembang, namun demikian norma-norma yang merupakan warisan dari para pendahulu tersebut rupanya masih dianggap sezaman. Dengan kata lain, tetap aktual untuk digunakan sebagai tuntunan bujang-cuene sekarang. Tidak heran kalau kemudian upacara ngarot terus-menerus diselenggarakan demi mewariskan normanorma tersebut.

Pewarisan norma dianggap sangat penting, mengingat apabila melihat lebih dalam dari upacara ngarot, upacara ini memiliki empat fungsi bagi masyarakatnya.Yakni, fungsi norma sosial, pengendali sosial, media sosial, dan pengelompokan sosial. Keempat fungsi tersebut merupakan satu kesatuan yang tidak dapat dipilah satu dengan lainnya. Sebabnya, upacara ngarot bukan saja identik sebagai sebuah norma, akan tetapi juga sebagai filter, media sosialisasi pendidikan, dan sarana silaturahmi bagi masyarakatnya.
Terlepas dari keempat fungsi di atas, ada dua fungsi lain yang melekat pada penyelenggaraan upacara. Yakni, fungsi pelestarian seni tradisi. Melalui upacara ngarot, tari topeng dan apalagi ronggeng ketuk yang sudah mulai terpinggirkan, akan lestari adanya. Selanjutnya, terkait dengan trend wisata budaya lokal maka upacara ngarot dikembangkan sebagai aset budaya Indramayu sebagaimana yang tertuang dalam TAP MPR RI No. IV/MPR/1978 mengenai arah dan kebijaksanaan pembangunan umum di bidang pengembangan kepariwisataan. Pengembangan kepariwisataan perlu ditingkatkan dan diperluas untuk meningkatkan penerimaan devisa, memperluas lapangan kerja, dan memperkenalkan kebudayaan. Pembinaan serta pengembangan pariwisata dilakukan dengan tetap memperhatikan terpeliharanya kebudayaan dan kepribadian nasional. Pembinaan serta pengembangan pariwisata dalam negeri lebih ditujukan kepada pengenalan budaya bangsa dan tanah air.

\section{DAFTAR SUMBER}

\section{Jurnal/ Laporan Penelitian}

Al-Hasani, Mohamad Muwafiqilah, Oksiana Jatiningsih.

"Makna Simbolik dalam Ritual Kawit dan Wiwit Pada Masyarakat Pertanian di Desa Ngasemlemahbang Kec. Ajibarang Kab. Sleman" dalam Kajian Moral dan Kewarganegaraan Vol. 03Nomor 02 tahun 2014. Hlm. 1220 1236.

Herlinawati, Lina. "Ngaruat Solokan di Desa Cihideung Kecamatan Parongpong Kabupaten Bandung Barat" dalam Jurnal Patanjala Vol. 3 No. 2 Juni 2011. Hlm. 296-314.

Hidayat, Lina Marliana. "Pertunjukan Ronggeng Ketuk dan Topeng pada Upacara Ngarot di Desa Lelea Kabupaten Indramayu (Sebuah Kajian Interaktif Simbolik)" dalam Panggung Vol. 24 No.1. Maret 2014. Hlm. 59-70.

Intani T., Ria. "Pengobatan Tradisional di Kalangan Anak-anak (Studi Kasus di 
Kecamatan Soreang)" dalam Jurnal Patanjala Vol. 7 No. 3. September 2015. Hlm. 509-524.

"Fungsi Upacara Pertanian pada Masyarakat Guradog Kabupaten Lebak" dalam Jurnal Patanjala Vol. 1 No. 1 Maret 2009. Hlm. 84-95.

Kasnodihardjo."Lebih Jauh Mengenal Metode Pengamatan" dalam Media Litbangkes Vol. II/No. 3/1992.

Merlina, Nina. "Upacara Huluwotan: Ritual Pada Masyarakat Gambung Desa Mekarsari Kabupaten Bandung" dalam Jurnal Patanjala Vol. 7 No. 2 Juni 2015. Hlm. 249-262.

Nisfiyanti, Yanti. "Kajian Nilai Budaya dalam Upacara Mapag Sri di Desa Lelea" dalam Jurnal Patanjala Vol. 3 No. 3September 2011. Hlm. 442-455.

Rahmawati, Neni Puji Nur. "Nilai Pendidikan dalam Budaya Menanam Padi Suku Dayak Kanayatn di Kalimantan Barat" dalam Jurnal Patanjala Vol. 4 No. 1.Maret 2012. Hlm. 14-24.

Rusnandar, Nandang. "Seba, Puncak Ritual Masyarakat Baduy di Kabupaten Lebak Provinsi Banten" dalam Jurnal Patanjala Vol. 5 No. 1.Maret 2013. Hlm. 82-98.

Somantri, Ria Andayani. "Sistem Gotong Royong pada Masayarakat Baduy di Desa Kanekes Provinsi Banten" dalam Jurnal Patanjala Vol. 4 No. 1.Maret 2012. Hlm. 137-151.

Tresnasih, Ria Intani., Suwardi A.P., Enden Irma R., Yeti Tresnawati., Dian Dianawati., Ecos.1992.

Upacara Ngarot di Desa Lelea, Kecamatan Lelea, Kabupaten Indramayu. Laporan Perekaman. Depdikbud, Dirjen Kebudayaan, Direktorat Jarahnitra: P3NB Jawa Barat.

Tresnasih, Ria Intani \& Lasmiyati. 2015. Upacara Ngarot. Pencatatan Warisan Budaya Takbenda (WBTB). Disbudpar Provinsi Jawa Barat.

\section{Buku}

Anonim.

Tata Upacara Adat Tradisional Tani di Desa.

Bungin, Burhan H. M. 2009

Penelitian Kualitatif. Jakarta: Prenada Media Group.

Dasuki, HA. 1977. Sejarah Indramayu.

Ekadjati, Edi S, 1995. Kebudayaan Sunda, Suatu Pendekatan Sejarah (1). Jakarta: Pustaka Jaya.

Kasim, Supali. 2011. Menapak Jejak Sejarah Indramayu. Yogyakarta: Framepublishing.

Koentjaraningrat. 1990.

Kebudayaan Mentalitas dan Pembangunan. Jakarta: Gramedia Pustaka Utama.

Saebani, Beni Ahmad. 2012. Pengantar Antropologi. Bandung: Pustaka Setia.

Salana, 1987

Anjir Sejarah Carbon, jilid I, 1987.

Samian. 1992.

Sambutan Kepala Desa Lelea pada Upacara Adat Ngarot Tanggal 25 Nopember 1992. Indramayu.

Sumardjo, Unang, 1983 Meninjau Sepintas Panggung Sejarah Pemerintahan Kerajaan Cirebon 1479. 1809. Bandung: Tarsito.

\section{Internet}

"Tari Topeng Indramayu" dalam http://sanggarcendrawasih.wordpress.c om diakses tanggal 23 Maret 2013, jam. 12.05 .

Bapeda Kabupaten Indramayu dalam "Gambaran Umum Kondisi Daerah", diakses dari www.bappedaindramayu kab.go.id, tanggal 2 Februari 2016, jam 11.45 .

Hartati, Sri Trisna Dewi, "Peranan Dewi Sri dalam Tradisi Pertanian di Indonesia", diakses dari http://iaaipusat.worpress. com, tanggal 2 Februari 2014 jam 14.35 . 
"Adat Tradisi Ngarot", foto diakses dari http://nanakartawi.blogspot.co.id, tanggal 8 Februari, jam. 20.10.

"Tradisi Ngarot di Indramayu", foto diakses dari http://news.fajarnews.com, tanggal 8 Februari 2016, jam20.56.

"Persiapan Upacara Ngarot Indramayu", foto diakses dari http://www.bandungnews photo.com. Tanggal 8 Februari 2016, jam 21.37.

"Upacara Adat Ngarot", foto diakses dari http://www.kabar-cirebon.com, tanggal 8 Februari 2016, jam 21.52.

"Mengenakan Kostum Tari Topeng di Upacara Ngarot", foto diakses dari http://www.lpsn.infocontentcarpan, tanggal 7 Februari 19.08.

Sambut Musim Tanam Desa Lelea Gelar Tradisi Ngarot", foto diakses dari http://www.pikiran-rakyat.comjawabarat, tanggal 7 Februari 2016, jam. 19.35 .

"Makna yang Terkandung dalam Acara Adat", foto diakses dari http://www.tosupedia. com, tanggal 7 Februari 2016, jam 20.42 .

"Kisah Balada Primadona Ronggeng Terakhir", diakses dari http:/pensilwarnadesign. wordpress.com, 26 Pebruari 2016, jam 19.20 .

"Ajang Pesta Gadis dan Perjaka, Warga Lelea Gelar Tradisi Ngarot" diakses dari http://www.cirebontrust.com, pada 8 Juni 2016 Jam. 13.35. 